\title{
Orman Yangınları ve Sonrası: Orman Ekosistem Restorasyonu
}

\author{
Nedim Kemer ${ }^{1 *}$ \\ ${ }^{1 *}$ Ankara Bilim Üniveristesi, Güzel Sanatlar ve Tasarım Fakültesi, İç Mimarlık ve Çevre Tasarımı Bölümü, Ankara, Türkiye, (ORCID: 0000-0002-9655-4715), \\ nedkem@gmail.com
}

(İlk Geliş Tarihi 10 Aralık 2021 ve Kabul Tarihi 31 Ocak 2022)

(DOI: $10.31590 /$ ejosat.1054290)

\begin{abstract}
ATIF/REFERENCE: Kemer, N. (2021). Orman Yanginları ve Sonrası: Orman Ekosistem Restorasyonu. European Journal of Science
\end{abstract} and Technology, (33), 373-381.

\section{$\ddot{\mathrm{O} z}$}

Son yıllarda dünya genelinde ve Türkiye'de sayıları ve büyüklükleri endişe verici boyutlarda artan orman yangınları önemli biyosfer kaynakları olan ormanlar için çok ciddi alarm vermektedir. Türkiye'de üst düzey devlet kurumlarından, halk tabanına; bilim insanlarından orman ürünü tüketicilerine kadar geniş paydaşlar çerçevesinde yangınları önleme, söndürme ve rehabilitasyon çalışmalarına ve genel olarak ormanların yönetimine dair büyük görüş ayrılıkları bulunmaktadır. Bu farklılıkların temelinde tüm paydaşlar arasında bir vizyon birliği olmaması, orman ekolojisi ve sağlıklı ormanların doğal yapı taşlarına dair ortak bir anlayış ve ortak bir bakış açısı bulunmamasıdır. İyi niyetli de olsalar uygulamaya yönelik çalışmalar ve girişimler, çıkış noktalarındaki ayrılıklardan dolayı uzun süreli olamamakta ve bütünsel fayda sağlayamamaktadır. Bu unsurların her kesim tarafından doğrulukla karşılıklı olarak anlaşılması büyük önem taşır. Bu çalışma öncelikle kamuoyundaki bu ortak vizyon eksikliğini bilimsel verilere dayalı bilgi desteği ile gidermeyi amaçlamaktadır. İkinci olarak da derlenen bilgi ve veriler ışığında, yangın geçiren orman arazilerine ekosistem odaklı yaklaşımlarla iyileştirme ve onarım planları için öneriler geliştirmektir. Çalışma kapsamında, orman olgusuna ağaç varlığının ötesinde, biyolojik çeşitlilik ilkeleri ile geniş bir çerçeveden bakarak ormanlar ve benzeri doğal sistemlerin altlarında yatan ekolojik unsurların önemleri bilimsel verilerle irdelenmiştir. Doğal sistemlerin evrimleşme sürecinin belirleyici unsurlarından olan yangınlar, ormanların kendilerini yenileme kapasiteleri içerisinde kalan aralıklar ve ölçülerde meydana geldiği sürece, eşitleyici ve yeni bir başlangıç firsatı sağlayarak biyolojik çeşitliğe ve gençleşmeye olanak tanıyan olumlu faktörlerdir. Gerek yangınları başlamadan önlemek gerekse de yangından sonra ormanların yeniden tesisi çalışmaları ve sonrasında ormanların sürdürülebilir yönetimi bağlamında sağlıklı doğal ormanların nasıl olması gerektiğini veya neyin orman olmadığını anlamak ve buna uygun politikalar ve eylemler geliştirmek orman kaynaklarının sürekliliği açısından büyük öneme sahiptir. Ortak bir toplumsal vizyon oluşumunun ağırlık merkezinde yer alan en birleştirici unsur rasyonel ve bilimsel verilere dayalı bilgi birliğidir. Çalışmada sonuç olarak, ulusal 'Çevre Düzeni Planlarına' entegre olacak şekilde hasar tespiti haritaları ve sonrasında koruma, iyileştirme ve restorasyon amaçlı plan öngörülerinde bulunulmuştur.

Anahtar Kelimeler: Orman Yangını, Orman Ekolojisi, Orman Toprağı, Biyolojik Çeşitlilik, Orman Yangını Restorasyonu, Orman Ekosistem Restorasyonu, Toprak Ekolojisi.

\section{Forest Fires and Post-Fire Actions: Forest Ecosystem Restoration}

\begin{abstract}
In recent years, forest fires have alarmingly increased in numbers and magnitudes throughout the world and Turkey, threatening Earth's crucially important biosphere resources. There are vast differences of opinion on fire prevention, extinguishing and restoration efforts, and forest management in general among a wide range of stakeholders from high-level state institutions to the forest product consumers to the grassroots in Turkey. The basis of these differences is the lack of unity of vision among all stakeholders, lack of a mutual understanding and perspective on forest ecology and natural building blocks of healthy forests. Even if they are well intended, all rehabilitation initiatives and implementation efforts with restoration focuses cannot have long-term effects and cannot provide holistic benefits due to the differences in the primary motives. It is of great importance that the scientific facts on forest ecology are comprehended thoroughly and agreed upon by the great majority of all parties. This study initially aims to provide the public with a shared vision constructed by scientific information. Secondly, in the light of the scientific information acquired, mitigation and restoration recommendation plans with ecosystem-based approaches are developed. Based on the fact that forest lands are more than
\end{abstract}

* Sorumlu Yazar: nedkem@gmail.com 
mere trees, this study demonstrates the importance of ecological components and biological diversity underlying forests and similar natural systems in the context of fires. Fires are one of the determinants of the evolution process of natural systems. Forest fires are positive phenomena that enable rejuvenation and support biodiversity by equalizing and allowing a fresh start opportunity, as long as they occur at intervals and measures that remain within the regeneration capacity of forests. It is imperative to understand and explain what a healthy natural forest is and what it is not, both in preventing forest fires, reforestation after the fire, and sustainable management of forests. Mutually shared knowledge-based unity and rational scientific information are the most unifying elements for the common consensus and vision. In conclusion, a two steps healing process is recommended. First, inventory of damage assessment; consequently, the conservation and restoration plans, eventually to be integrated into the National Regional Environment Plans (Çevre Düzeni Planı.)

Keywords: Forest Fires, Forest Ecology, Forest Soil, Biological Diversity, Forest Fire Restoration, Forest Ecosystem Restoration, Soil Ecology, Forestry.

\section{Giriş}

Orman yangınları, son yıllarda çok büyük ve küresel bir problem haline gelmiştir. Hemen her kıtada ve ülkede görülen büyük yangınlar, doğal nedenlerle veya insan faaliyetlerinin sonucunda başlamış olsalar da yangınlar bağlamında ormanların genel yönetim politikaları çok yönlü olarak sorgulanmaktadır (Noss ve d., 2006; Elmas ve Sönmez, 2008). İklimsel sicaklık ve yağış rejimlerindeki değişiklikler, göçler nedeniyle kırsal nüfusun azalması, doğal çevrelerde ve ormanlarda yabani hayvanlar ve besi hayvanlarının azalması ve bu nedenle yanıcı organik maddelerin orman tabanlarında aşırı miktarlarda birikmesi gibi sebeplerin orman yangınları üzerindeki doğrudan ve dolaylı etkileri akademik çerçeveden kamuoyuna kadar geniş çevrelerde tartışılmaktadır (Alkan, 2014; North, 2015; Bilgili, Demir, ve Daşc1, 2017). Son yıllarda her iki yarı-kürenin yaz aylarında çok yüksek değerlere ulaşarak artış gösteren sıcaklıkların da etkileri nedeniyle yangınlar aşırı büyüyerek, kontrol edilemeden yayılmış haftalarca ve aylarca devam etmiştir. Akyol ve Tolunay (2006), 'Türkiye'de sürdürülebilir orman yönetimi' konusunda gerçekleştirdikleri geniş kapsamlı çalışmaları ile ormanlar üzerindeki çok başlı yönetim karmaşasından, sosyal, ekonomik ve ekolojik sorunlara kadar çeşitli baskıları irdeleyerek uzman eğitim düzeyleri ve değerlendirme ölçüt kriterlerinde karşılaşılan farklılıkların süreci zorladığını tespit etmişlerdir. Orman yangınlarının çıkış nedenlerini azaltmaya yönelik önlem odaklı öneriler, söndürme çabaları ve orman sahalarının yangınlardan sonra korunarak hızla tekrar ağaçlandırılmak suretiyle rehabilitasyon ve restorasyon çalışmaları hakkında da çok farklı görüşler vardır (Elmas ve Sönmez 2008; Moreira, 2012). Bugün gelinen noktada Türkiye'de üst düzey devlet kurumlarından, halk tabanına; bilim insanlarından orman ürünü tüketicilerine kadar geniş kapsamlı paydaşlar çerçevesinde yangınları önleme, söndürme ve rehabilitasyon çalışmalarına ve genel olarak ormanların yönetimine dair büyük görüş ayrılıkları olduğu görülmektedir. Bu farklılıkların temelinde tüm paydaşlar arasında bir vizyon birliği olmaması, ormanlara dair ortak bir anlayış ve ortak bir bakış açısı bulunmaması yatmaktadır. Dolayısıyla iyi niyetle de olsa uygulamaya yönelik çalışmalar ve girişimler, çıkış noktalarındaki ayrılıklardan dolayı uzun süreli ve bütünsel fayda sağlayamamaktadır. $\mathrm{Bu}$ çalışmanın amacı öncelikle kamuoyundaki bu ortak vizyon eksikliğini bilimsel verilere dayalı bilgi desteği ile gidermektir. İkinci olarak da derlenen bilgi ve veriler 1şığında, yangın geçiren orman arazilerine ekosistem odaklı yaklaşımlarla iyileştirme ve onarım planları için öneriler geliştirmektir. Çalışma kapsamında, yangınlar bağlamındaki farklı görüşler ve fikirler geniş bir çerçeveden değerlendirilerek, orman olgusuna ağaç varlığının ötesinde bakılarak ormanlar ve benzeri doğal sistemlerin altlarında yatan ekolojik unsurların önemleri bilimsel verilerle irdelenmiştir. Gerek orman yangınlarını başlamadan önlemek gerekse de yangından sonra tekrar ağaçlandırma çalışmaları ve sonrasında ormanların sürdürülebilir yönetimi bağlamında öncelikle gerçek ve sağlıklı bir ormanın nasıl olması gerektiğini veya ne olmadığını anlamak çok yerinde olacaktır. Ortak bir toplumsal vizyon oluşumunun ağırlık merkezinde yer alan en birleştirici unsur rasyonel ve bilimsel verilere dayalı bilgi birliğidir.

\section{Yerkürede Yaşam Daima Var Olmak Eğilimindedir.}

Doğada canlılık her yerde ve her koşulda var olmak eğilimindedir. Doğaya yapılacak her müdahalede doğanın doğallıkla ve doğal çevresel süreçlerle ne yapmak isteyeceğini anlayıp onun önünü açmak her zaman için en doğru yaklaşım olacaktır. Yerkürede tek bir santimetrekare dahi canlılıktan yoksun değildir. Doğal süreçlere, ekolojik dinamiklere engel olunmadıkça ve onların içsel döngüleri ile çelişecek faaliyetler yapılmadığ 1 sürece canlılık devam etme eğilimindedir. Tahrip olduğu için veya başka nedenlerle yenilenmesi istenilen doğal çevrelerde öncelikle insan faaliyetlerini sınırlayarak kısmi ölçülerde hazırlıkla destek olduktan sonra doğal süreçleri beklemek doğanın kendini yenilemesi için yeterli olacaktır. Sabırla ve bilinçle desteklendiğinde hemen her yer kendine özgü bir bitki örtüsü ile kaplanabilecektir. Lav ile kaplanan yanardağ yamaçları dahi yeterli zaman tanındığında önce mikroorganizmalar, sonrasında öncü bitkiler nihayetinde de ormanla kaplanabilmektedir. Doğal çevrelerin kendilerini yenilemelerine dair zaman gereksinimleri bir insan ömrü baz alınarak ölçülendirilemez. 'Orman vasfını yitirmiş olmak' ifadesi geri dönüşü olmayan bir durumu tanımladığı için maalesef doğallıktan uzak ve gündelik bir ifade olarak kalır. Geleneksel ormancılık politikaları hemen tüm orman sahalarını kereste üretim sahaları olarak sürdürüp yönetmektedir. Bu orman yönetim programını öğrendiğimiz toplumlar böyle bir genellemeyi geride bırakarak ormanlarını endüstriyel ve doğal olmak üzere farklı sinıflarda yönetmektedir (Gülen ve Özdönmez, 1981; Gümüş, 2016; McEwan,2020). Homojen bir yapıda tek bir türden oluşan ormanlar için monotop tanımı kullanılır. Doğal olsalar da ağırlıklı olarak insan müdahaleleri etkisinde yetişmiş, büyük bir kısmı tek türün hakimiyetinde ağaç tarlaları şeklinde olan bu tür ormanların yangına maruz kalmaları halinde yerlerine aynılarının tekrar tesis edilmesi gerekmeyebilir. Onların yerine, biyolojik çeşitliğe sahip, flora ve fauna açısından zengin, çok katmanlı ve karşılıklı etkileşim halinde türlerden oluşan orman kompozisyonlarının oluşturulması göreceli olarak çok daha sürdürülebilir doğal çevrelerin gelişimini sağlayacaktır. Doğal yaşamın çok yönlü temsilcilerini içlerinde barındıran, geniş tür çeşitliğine sahip ormanlar arıcılik, turizm, rekreasyon, ve benzeri ekonomik faaliyetleri de destekleyeceği gibi sosyo-kültürel açıdan da büyük zenginlikler sunabilecektir.

\subsection{Bütüncül Organizmalar Olarak Ormanlar ve Orman Ekosistemi}

Ağaçlar orman ekosistemleri topluluklarının dışarıdan görülen en büyük bireyleri olduğu için ormanların salt ağaçlardan 
oluştuğu algısı hakimdir. Aynı yanılsama ile, erozyonun da büyük ölçüde ağaçlar tarafından engellendiği düşünülür. Tahrip olan orman sahalarını restore etmeye yönelik iyi niyetli çalışmalar ağırlıklı olarak fidan dikimine odaklandıkları için bütüncül ormanlar yerine sağlıksız ağaç tarlaları oluşturulmaktadır. Herhangi bir yere, sadece herhangi bir ağaç fidanı dikerek orman değil, ancak bir tür tarımsal üretim sahası veya endüstriyel orman benzeri ağaçlıklar tesis edilebilir. Şen ve Güngör'ün (2018) çalışmalarında da vurgulandığı gibi ağaçlandırma çalışmalarında kereste üretimi esastır ve o doğrultudaki verimliği yüksek tutmak için en uygun türler seçilir. Ancak bu oluşumlara gerçek orman diyebilmek çok zordur. Ağaç tarlaları orman değildir, zaman içerisinde biyolojik çeşitlik içeren, zengin habitatlara dönüşseler dahi meşcere tabir edilen sınıflarla nitelenen yarı doğal ormanlar olmaktan öteye gidemezler. Gerçek, doğal ormanlar ağaçlardan çok daha fazlasıdır.

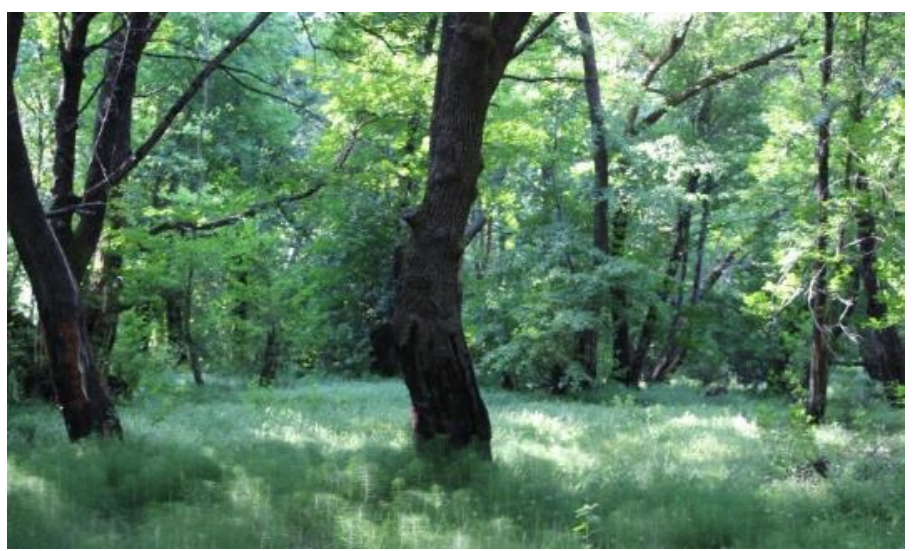

Şekil la: Çok katmanlı ve să̆lıklı bir sığla ormanı. A multilayered, healthy sweetgum forest, (Liquidambar orientalis). Köyceğiz, Muğla. (Orijinal fotoğraf yazara aittir, Photograph by the author, 2017)

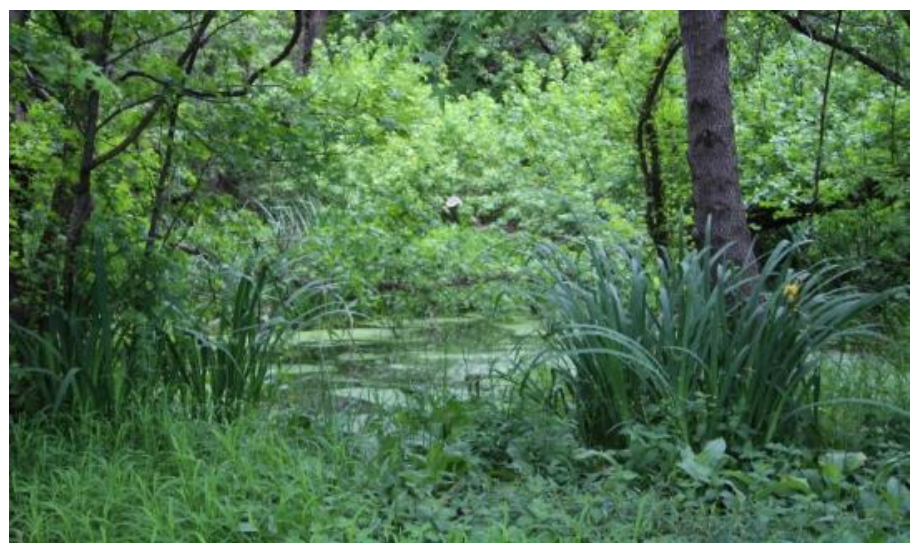

Şekil 1b: Çok katmanlı ve săğlklı bir sığla ormanı. A multilayered, healthy sweetgum forest, (Liquidambar orientalis). Köyceğiz, Muğla. (Orijinal fotoğraf yazara aittir, Photograph by the author, 2017)

Ormanlar çok geniş bir canlılar ve cansızlar bütünüdür. Sağlıklı doğal ormanlar bitkilerden hayvanlara geniş kapsamlı ve çok katmanlı unsurlardan oluşur. Ormanlar, topraktan yüksek ağaca kadar çok çeşitli mikroorganizmalar, hayvanlar aleminin üyesi büyüklü küçüklü türler, otsu bitkiler, yer örtücü ve tırmanıcı bitkiler, çalılar, alçak ve yüksek ağaçlar içeren katmanlar topluluğudur. En üst seviyede yer alan ve birden fazla türden oluşan ağaçlar ormanların tacıdır. Ormanlar bölgesel ve mevcut koşullara bağımlı olarak değişen sürelerde kademeler ve aşamalarla olgunlaşırlar. Ormanların öncü türlerle başlayıp e-ISSN: 2148-2683 aşamalı oluşumlarla gelişmesi, bir önceki oluşumun ardından ve onun sağladığı olanaklarla onun üzerinde gelişerek ve bir sonraki kompozisyonların önünü açarak olgunlaşmasına orman süksesyonu (forest succession) denir. Süksesyonun aşamalarında yer alan bazı türler öncü görevlerinin tamamlanmasıyla beraber ileri aşamalarda ortamdan çekildikleri gibi bazı türler de öncülük görevlerinin sonlanmasına rağmen orman kompozisyonunda sürekli kalmaya devam edebilirler (Finegan, 1984; Dalling, 2008). Sonuç olarak süksesyonla ve doğal oluşumlar sonucunda, aşamalar ile olgunlaşan bir orman sağlıklı oluşunun yanında biyolojik çeşitliliği de destekleyen zengin katmanlar içeren bir ekolojik sistemler topluluğudur. Orman temel yapı taşlarının kendi iç dinamikleri, çevresel ve iklimsel döngülerin etkileri ve insan faaliyetleri sonucunda oluşan orman kompozisyonları sürekli bir değişim ve devinim içerisindedir. Bu tür etmenlerin yoğunluklarına bağlı olarak ormanlar doğal, yarı doğal veya doğal olmayan gibi ayrımlar gösterseler de geniş fauna barındıran, insan topluluklarına kültürel ve ekonomik katkılar sağlayan, biyolojik çeşitliğe sahip ormanlar ekolojik zenginlik açısından ideal ve sağlıklı doğal oluşumlardır. Bir diğer deyişle, orman ekosistemi canlılığın yapı taşları olan enerji, mineraller ve su, (karbon, oksijen, hidrojen gibi) temel elementlerle; (azot, fosfat, potasyum, kalsiyum, magnezyum gibi) bir dizi diğer elementlerin bileşikten bileşiklere dönüştürülüp enerji yüklenerek sürekli el değiştirdiği yoğun bir materyal, enerji ve ekonomik faaliyetler döngüsüdür (Ericsson, 1994).

\subsection{Orman Toprağı Ekosistemi}

Bütüncül olarak canlı bir varlık olan toprak, başlı başına ağaçlardan çok daha önemli ve orman ekosistemi için hayati bir orman yapıtaşıdır. Toprak, içerdiği besin maddeleri ve minerallerin ötesinde çok değerli mikro ve makro organizmalara ev sahipliği yapar. 'Toprak edafonu' (soil edaphon) olarak tabir edilen bu organizmalar topluluğu kısmen veya tamamen toprak içerisinde yaşayan mantarlar, likenler, bitkiler ve hayvanlar aleminin üyesi mikroskobik ve küçük organizmalar topluluğudur. Edafonun fauna boyutunda hayvanlar aleminin üyesi amipler, kamçılılar (microfauna), nematodlar (mesofauna) ve solucanlar, karıncalar, kırkayaklar (macro fauna) ve bunlar gibi çeşitli organizmalar topluluğu bulunur. Sağlıklı orman ekosistemlerinin bütüncül canlılığının önemli organları olarak sürüngenler, kuşlar ve memelilerden oluşan geniş bir hayvan varlı̆̆ı (megafauna) toprak edafonunun üzerinde yer alır (Wolters, 1991; Blair 1997). İdeal, sağlıklı, bütüncül ve dolayısı ile de sürdürülebilir, doğal bir orman ekosistemini oluşturan katmanlarda yer alan biyotik her bir tür ve abiyotik her unsurun varlığı hayati önem taşır.

Mikoriza (mychorriza), bitkilerin sağlıklı gelişimlerini destekleyen, simbiyotik bir biyolojik oluşumun adıdır; mantar ve kök kelimelerinin Latince adlarından türetilmiştir. Doğadaki bitkilerin \% 96'sı mikoriza mantarları ile simbiyotik bir birliktelik içerisindedir (Kara ve Tilki, 2001; Ortaş, 1999). Mikoriza mantarları bitki köklerine yerleşerek bitkiden karbonhidrat tedarik ederken, bitki köklerinin su ve mineral alımını hızlandırır ve kolaylaştırır. Mikoriza mantarları ile simbiyotik iş birliği içerisinde bulunan bitkiler kuraklığa ve diğer mantar kaynaklı hastalıklar ile nematod gibi parazitlere karşı da direnç kazanırlar (Srivastava ve Sharma, 2011; Erzurumlu ve Kara, 2014).

Biyolojik Kaymak Katmanı (Biological Soil Crust) toprakta bir arada yaşayan algler, likenler ve bakteriler gibi mikroorganizmaların salgıları vasıtası ile toprak partikülleri, 
mineraller ve organik maddelerin birbirine yapışması ile toprağın en üst katmanında gerçekleşen kabuk benzeri biyolojik bir oluşumdur. Biyolojik toprak kaymağı oluşumu erozyona engel olarak toprağı korurken toprakta yaşamsal döngünün de (süksesyon) başladığı ilk aşamadır (Bowker, 2007). Biyolojik kaymak katmanı canlılıkla oluşan, canlılık içeren biyolojik bir toprak yapısı olarak özellikle tahrip olan ekosistemlerin restorasyonunda hayati önem taşır. Kaymak katmanının kırılıp ufalanması toprağın en kıymetli unsurlarını rüzgar ve yüzey akışı erozyonuna karşı korumasız bırakacaktır. Biyolojik kaymak katmanının varlığı özellikle yarı kurak ve kuru iklim bölgelerinde çok önemlidir. Brianne ve arkadaşları (2020) bu tür iklim bölgelerdeki yangınların biyolojik kaymak katmanı varlığını \%50 azalttığını tespit etmişlerdir.

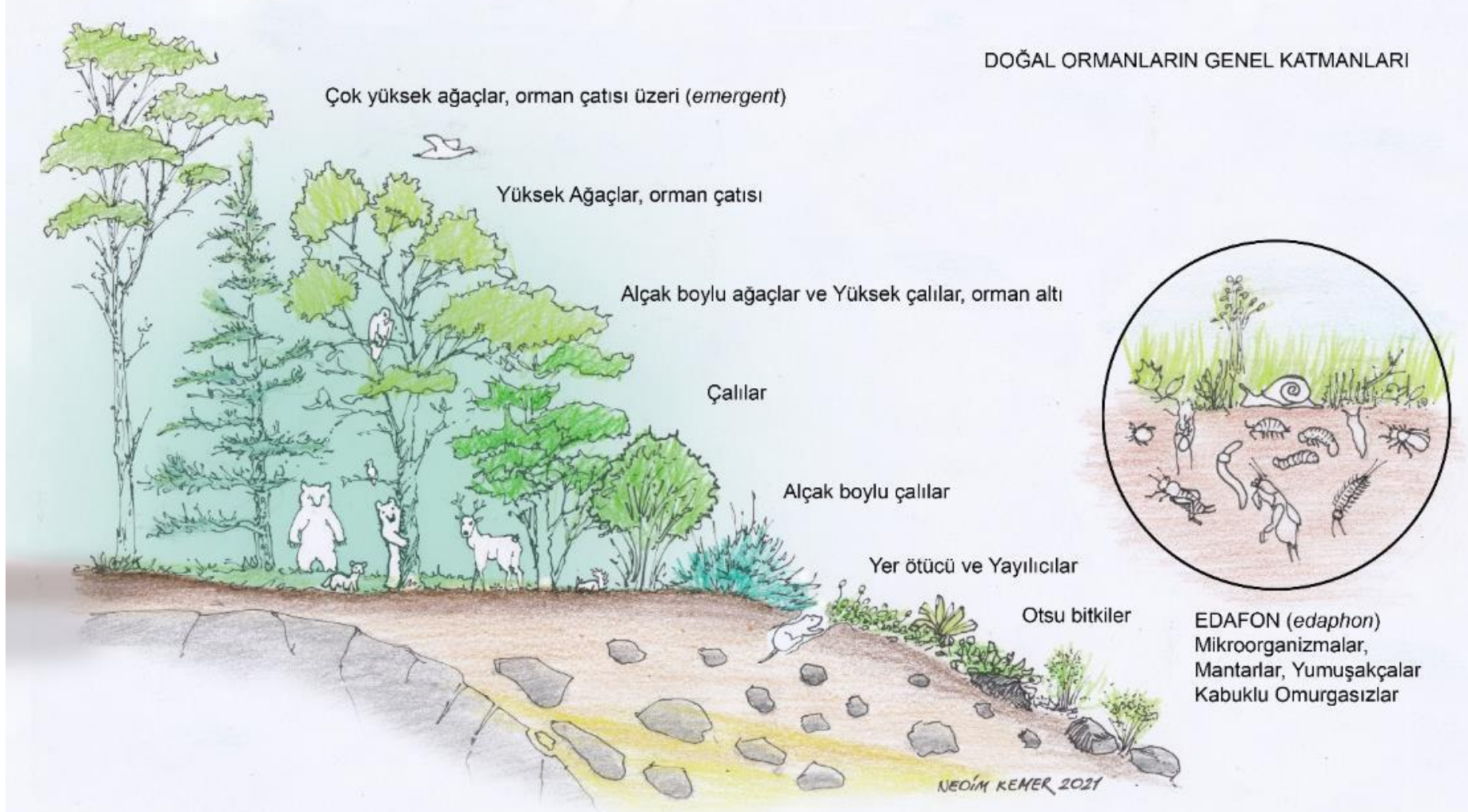

Şekil 2. Doğal orman oluşumlarının katmanlarını gösteren tipik bir kesit. A typical cross section showing layers of natural forest formation. (Imge yazarin orijinal eseridir, Image by the author, 2021)

Killi topraklarda kuruma esnasinda k1lcal hareket ile (capillary action) üst katmanda biriken mikroskobik boyuttaki kil tozlarının kururken çimento etkisi ile birbirine yapışarak oluşturduğu kabuk, biyolojik kaymak katmanından farklıdır. Killi topraklarda oluşan kabuk, toprağın hava ve su almasını sınırlar, mikroorganizma faaliyetlerini zayıflatır, çimlenen tohumların toprak üzerine çıkarak ışığa erişmesine engel olur ki tüm bu etkiler toprakta genel olarak canlılığın kisitlanmasına sebep olur. Killi topraklarda gerçekleşen kabuk oluşumu (soil crust) ile 'Biyolojik Kaymak Katmanı' (Biological Soil Crust) tabir edilen oluşum karıştırılmamalıdır. Killi toprağın kabuğunun kırılması topraktaki canlılığa yarar sağlayacak iken, biyolojik toprak kaymağının kırılıp ufalanmaması ve önemle korunması gerekir. Ayakla basmak, tekerlekli ve paletli araçlarla ezmek, yangın atıklarını sürükleyerek taşımak gibi faaliyetler biyolojik toprak kaymağını tahrip edecektir.

Yerkürede yaşam 3.7 milyar yıl önce mikroorganizmalar ile başlamış, bugün de mikroorganizmalar sayesinde devam etmektedir. Tahrip olan habitatlar ve ekosistemlerde, doğal ve kırsal çevrelerde ve tüm biyolojik sistemlerde gerçekleştirilecek rehabilitasyondan ağaçlandırmaya bütün çalışmalara mikroorganizma varlıklarının korunması ve desteklenmesi ile başlanılmalıdır (Chotte, 2005; Giri, vd., 2005).

\subsection{Orman Kompozisyonları ve Ekolojik Dinamikler}

Doğal ve sağlıklı ormanlar, ekolojik sistemler ve habitatlarda bir arada yaşayan çok çeşitli biyotik türlerin karşılıklı etkileşimler içerisinde oluşturdukları çok katmanlı kompozisyon zenginliği biyolojik çeşitlilik (biodiversity) şeklinde tanımlanır. Biyolojik çeşitliğe sahip farklı ekolojik sistemler birbirleri ile de karşılıklı etkileşim halinde bulunarak bölgesel ve daha geniş uzantılı etkilerle yeryüzündeki küresel canlılığa büyük katkı sağlarlar. Biyolojik çeşitlilik kaynakların ve enerjinin verimli kullanımı esasına dayalı olarak dirençli ve sürdürülebilir sağlıklı orman gelişimleri açısından büyük önem taşır. Tarımsal üretimde ekonomik verimlilik, doğal çevrelerin estetik özellikleri, tüm kırsal ve kentsel çevrelerin sağlığ kaynakların erişilebilirliği tümüyle biyolojik çeşitliğe sahip zengin ve dengeli ekolojik sistemlere bağlıdır. Biyolojik çeşitlik kavramı küresel boyutta ilk olarak 1992 senesinde Rio'da gerçekleştirilen sürdürülebilirlik temel esaslı Birleşmiş Milletler Dünya Çevre Zirvesinde gündeme gelmiştir. Bu zirvenin önemli 
kazanımlarından birisi olarak küresel biyolojik çeşitliliğin uluslararası bir anlaşma ile korunması kararı alınmıştır. Bugün gelinen noktada Türkiye biyolojik çeşitlilik mukavelesinin katılımcısı 196 ülkeden birisidir. Biyolojik çeşitlik olgusu, kentsel - kırsal ve yabani çevrelerin doğal ve estetik zenginliğine bölgesel ölçeklerde ve tüm yönetsel sınırlar ötesinde katkılar sağlarken, Edward Wilson'ın (1984) senesinde adını da koyarak ortaya attığ 1 biyofili tezini de destekler. Temel olarak insana dair içsel ve psikolojik bir olguyu tanımlayan biyofili tezi bütün biyolojik varlıkların, doğal çevrelerde bir arada olmak eğilimi hipotezinden hareket eder.

Orman ekosistemi bir doğal kaynak üretim sahası olarak biyosferin ve yeryüzündeki yaşamın en büyük destekçilerindendir (Sedjo, Roger A. Ve Daniel Botkin, 1997). Dünya ormanları farklı ağaç türlerinin doğal süreçlerle evrimleşerek ve bir araya gelerek oluşturdukları kompozisyonlar ve altlarında barındırdıkları ve kendilerinin de üyesi oldukları ekosistemlerden oluşur. Tek bir türün hâkim (dominant) olduğu ve o asal ağacın ismi ile anılan doğal ve yarı-doğal orman oluşumlarında dominant türün yanında başka ağaç türleri de yer alır. Örneğin kızılçam hakim ormanlarda meşe, akçaağaç, menengiç, üvez, keçiboynuzu, dişbudak, gibi ağaç ve ağaççık türleri de yer alır. Endüstriyel üretim amaçlı homojen monotop ağaçlıklarda dahi yerde o ağaçları besleyip destekleyen çok zengin bir biyokimya laboratuvarı bulunur.
Pioneer species tabir edilen öncü türler, özellikle de otsu tek y1llık bitkiler ilk olarak araziye yerleşip, toprağ 1 tutarak, yaşam koşullarını iyileştirerek ağaçların yerleşip yeşerebilmeleri için uygun zemin hazırlarlar (Dalling, 2008). Özellikle tahrip olan arazilerde ormanların doğal yayılımı da daima öncü türlerin açtığı yoldan ilerleyerek gerçekleşir. Bir bakıma orman süksesyonun başlangıcının ilk adımlarıdır. Yangınlar, yoğun tarımsal veya endüstriyel faaliyetlerle tahrip olan alanlarda öncelikle otsu bitkiler hızla büyüyüp ince, sık ve saçaklı, kılcal kök yapıları ile toprağ1 tutarak zemini iyileştirirler. Toprakta organik madde eksikliği ve ona bağlı olarak edafonu oluşturan mantar ve bakteriler gibi mikro organizmalar ile omurgalı omurgasız hayvansal yaşam kısıtlanıp toprak canlı tutulamadıkça; su tutulamadıkça bu arazilere dikilecek fidanlar da ya öleceklerdir ya da sistemler bütününe katkı sağlayamadan sağlıksız bir şekilde yaşamaya devam edeceklerdir. Sağlıklı bir orman ekosisteminde her canlı türü bütüne bir katkı sağlar. Sağlıklı bir orman oluşumu için sağlıklı bir orman ekosistem restorasyonu onun için de ön hazırlık aşaması son derece önemlidir. Aksi halde, acele ile dikilen ağaç fidanları, zemin henüz hazır olmadığından sağlıklı yaşayamayacaklardır veya zaten tahribat geçirmiş ve kendisini onarmaya çalışan bir doğal sisteme adeta yük olacaktır. Yangın artıklarını temizleme ve ardından dikim amaçlı yoğun insan faaliyetleri ne kadar iyi niyetli çabalar olsalar da faydadan çok zarar verebileceklerdir.

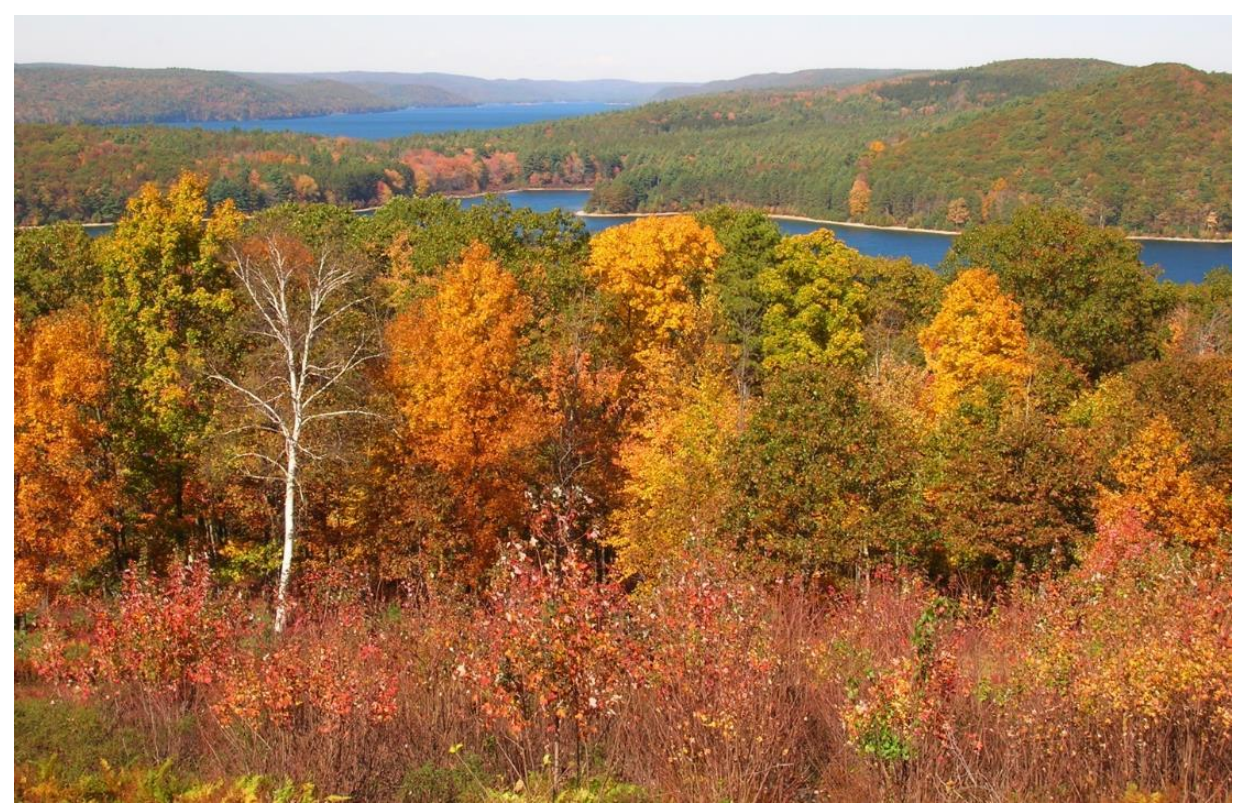

Şekil 3. Bir biyolojik çeşitlilik örneği olarak, karışı yaprak döken ormanı. A mixed deciduous forest, as a typical biodiversity example: Quabbin Reservoir, Massachusetts, North America. (Orijinal fotoğraf yazara aittir, Photograph by the author, 2009)

\section{Yangınlar ve Biyoçeșitlilikteki Rolü}

Yangın doğaya yabancı olmayan bir gerçekliktir. Akdeniz kuşağı ormanları da dahil olmak üzere dünya ormanlarının büyük bir çoğunluğu yangınlarla evrimleşmiş ekolojik sistemler topluluğudur. İnsan faaliyetleri sonucunda veya çeşitli doğal süreçlerle bazı yabancı ve egzotik istilacı bitki türleri doğal çevrelerde veya ormanlarda yayılarak orman kompozisyonlarının bozulmasına, yerli türlerin azalmasına veya yok olmasına sebep olurlar. Zaman içerisinde yerli de olsa bazı türler de çevreye hakim olduklarında ve sonrasında dominant tür olarak yaşlandıklarında sistem doğal olarak kendisini yenileyemeyecektir. Gerek istilacı türler gerekse de tek türün dominant olması nedeniyle endemik ve yerli türlerin ortamda azalıp doğal kompozisyonların bozulması biyolojik çeşitliği zayıflatır. Yangınlar, biyolojik çeşitlilik içermeyen zayıf ekosistemlere sahip, bu tür sağlıksız toplulukları (populasyon) ortamdan kaldırarak doğal çevrelerin zengin ve çeşitli türlerle kendilerini yenileyerek gençleştirmesine olanak tanırlar. Çok çeşitli canlı türünün eşit şanslarla katılımını sağlayarak yeni ve zengin ekosistemlerin başlangıcı için koşullar hazırlanmış olur. (Keeley, 2012). 
Yangınların şiddetleri ve tahribat etkileri çok farklı olabilir. Ancak hizla ve yüzeysel ilerleyerek, yüksek isılara erişmeden sadece üst örtüyü yakıp geçen yangınlar arkada yeni yaşamsal oluşumlar için çok uygun ve eşitlikçi sahalar açarlar. Tavşanoğlu ve arkadaşları (2015) çalışmalarında dumana ve isıl etkisine maruz kalmış otsu yapraklı türlerin tohumlarının görece hızlı çimlendiğini gözlemlemişlerdir. Öte yandan birikmiş yanıcı madde miktarına, bitki örtüsüne ve iklim koşullarına bağımlı olarak bazı yangınlar belirli alanlarda uzun süre devam ederek ve çok yüksek 1sılara erişerek ortamdaki tüm canlılığı tahrip edebilir. $\mathrm{Bu}$ tür alanların dikkatle tespit edilip kalan toprağın korunması, organik madde katkısı, tohum ve mikroorganizma ve mikoriza mantarı aşılaması yapılması gerekir. Yüksek 1sılar nedeniyle toprağın adeta piştiği, edafonun yok olduğu, tohumlar içerisinde embriyoların ve kökler gibi canlılık barındıran her organizmanın öldüğü bir zemine ağaç fidanı dikmek beklenen yararı zaten sağlamayacaktır. Yangınla evrimleşmiş tüm dünya ormanları için taban toprağı çok değerli canlılık rezervleridir. Toprakta bekleyen tohumların tekrar çimlenip, yüzey yangınlarında da köklerin tekrar yeşereceklerine inanmak ve toprağı korumak yeterli olacaktır. Bu sayede yangınlar, ormanlar ve doğal çevrelerin yararına işlemiş olarak, biyolojik çeşitliğe ve zenginliğe sahip gerçek ormanlar ve doğal yapıların oluşumu veya gençleşmesi (regeneration) doğallıkla sağlanmış olacaktır.

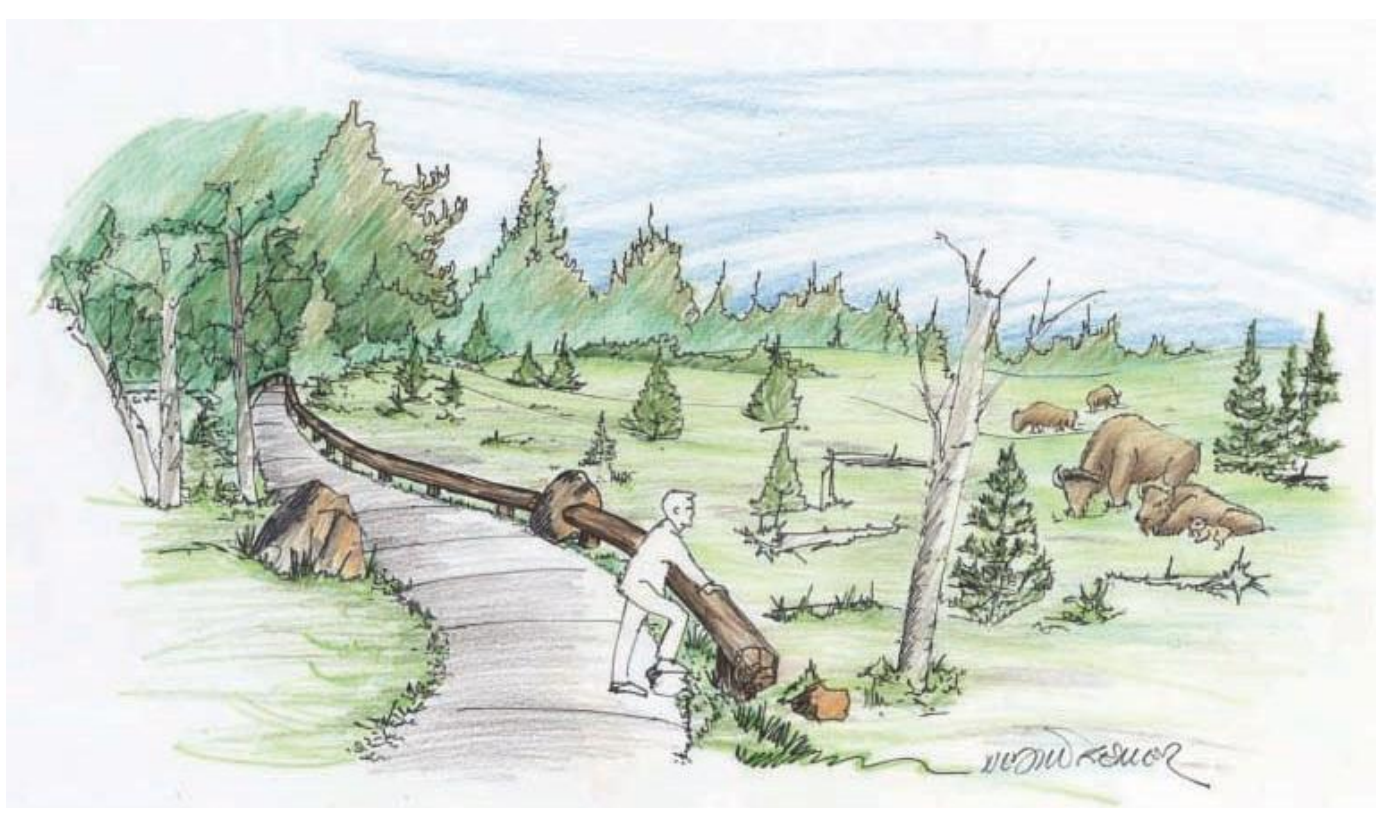

Şekil 4. Yellowstone A.B.D. Milli Parkı orman peyzajının doğal restorasyon süreci sonrasında ziyarete açılması. Yellowstone U.S.A. National Park forest landscape opening for visitation after the restoration period. (Imge yazarin orijinal eseridir, Image by the author. 2006)

1988 senesinde Amerika Birleșik Devletleri'nde Yellowstone Milli Parkı ormanlık arazilerinde yıldırımlardan kaynaklanan çok sayıda yangın birleşerek aylarca süren büyük bir felakete dönüşmüştür. Öncesinde, ABD Milli Parklar ve Orman yönetim politikaları her küçük yangını başladığı anda söndürmeye yönelik bir koruma programı yürütmüş olduğu için orman tabanlarında aşırı miktarda yanıcı madde birikmiş bulunmaktaydı. Dolayısı ile kontrol edilemeden aylarca süren bu büyük yangın çok yüksek 1sılara erişerek 320000 hektar araziyi tahrip etmiştir. Adeta sterilize olarak tohum rezervlerini kaybeden, mikroorganizma canlılı̆ı̆ından yoksun kalan bir kısım orman arazilerinin flora ve faunasıyla beraber tekrar canlanması yıllar almışıtır. Yanan alanlar tamamen kapatılarak insan faaliyetleri kısıtlanıp, korunmuş ve sabırla doğanın kendi kendisini onarması beklenmek suretiyle başarı sağlanmıştır. Bugün gelinen noktada orman ekosisteminin, tüm flora ve fauna zenginlikleriyle yeniden canlanarak habitatların ve ormanların gençleşerek, yenilendiği gözlemlenebilmektedir†.

\subsection{Yangın Sonrası}

Yangınlardan hemen sonraki dönemler dikkatle yönetilmesi gereken çok kritik dönemlerdir. Yangın geçiren bölgelerde iki noktaya çok dikkat edilmelidir. Birisi orman tabanındaki toprağın korunması; diğeri de yabancı tür istilasının önlenmesi. Akdeniz Bölgesinin de içinde yer aldığ 1 tropik ve sub-tropik kuşak ormanları yangınlarla evrimleşmiştir. İnsan faaliyetleri soncunda artan erozyon ve istilacı tür yayılımı problemleri orman ekosistemlerinin alışkın olmadıkları tehditlerdir. Yanan bölgelerdeki toprak içerisinde bulunan mineraller ile organik materyaller ve tohumlar ormanların kendilerini yenileme kaynaklarıdır, ancak erozyon ile kaybedilmeye de çok açıktır. Hayati bir kaynak olarak toprağın yerinde tutularak özenle korunmasına çok özen gösterilmelidir. Yangınlardan sonra arazide gerçekleştirilen temizlik, boşaltma ve restorasyon amaçlı yoğun faaliyetler bu kıymetli kaynağın, rüzgar ve yüzey akışı erozyonu ile kaybedilmesine sebep olabilmektedir. Dolayısı ile ormanın yenilenmesi çok gecikebilecektir.

\footnotetext{
†YAZAR, 2006 senesinde Yellowstone Milli Parkı'nda yangınlar sonrası restorasyonu ve parkın tekrar kullanıma açılması amaçlı genel yönetim planı hazırlama çalışmalarını gerçekleştiren ekipte görev almıştır.
} 
Küreselleşen dünyada ekonomik ve kültürel alışverişin arttığı, materyal erişimin hız ve kolaylık kazandığı günümüz yaşantısında, bitki ve hayvan türleri çok çeşitli köprüler ve kanallar sayesinde kolaylıkla hemen her yere erişerek yerel habitatları istila etmektedir. Özellikle de yangın geçiren sahalar yabancı bitki türlerinin istilasına karşı açık ve savunmasız kalırlar (Keeley ve Brennan, 2012). Yangınlardan sonra orman arazilerini kendi kaynaklarından yerli türler ile kendilerini restore etmelerine olanak tanıyacak şekilde bırakırken, yabancı türlerin istilasına karşı da korunma önlemleri alınmalıdır. Yabancı türler düzenli kontroller ve mekanik yöntemlerle araziden uzaklaştırılarak imha edilmelidir. Aksi halde istilacı yabancı ve egzotik türler hızla gelişecek, doğal sağlıklı bir süksesyona engel olacak ve dominant tür olarak da araziye hakim olabileceklerdir.

Tüm restorasyon çalışmaları biyolojik çeşitlik prensipleri çerçevesinde, doğal orman ekosistemi restorasyonu hedeflenerek yürütülmelidir. Hemen her yere, her hangi bir ağaç fidanı dikilemeyeceği gibi yanan, tahrip olan her orman sahasına da aynı reçete uygulanamaz. Masum ve iyi niyetli girişimler ile ve aceleyle dikilecek fidanlar başarılı olsalar bile bu oluşumlar çok uzun yıllar ağaç tarlası olarak kalacak ve bütüncül bir orman oluşumu ancak çok uzun yıllarda gerçekleşebilecektir. Öte yandan, göreceli, olarak daha duyarlı bölgeler belirlenmeden yapılacak onarım çalışmaları, finans, emek ve en önemlisi risk altındaki bölgelerde çok kıymetli olan zamanın hatalı kullanılmış olma riskini taşımaktadır. Plansız ve aceleci uygulamalarla ağaçlandırılan sahalar yeni yangın tehditlerine karşı da göreceli olarak daha dirençsiz olacaklardır. Öncelikle yanmanın şiddetine bağlı olarak hasar seviyesi tespit edilerek ve taban toprağının canlığı kontrol edilerek başlanılmalıdır. Mikro ve makro ölçeklerde çalışılacak bölgesel duyarlık ve rehabilitasyon planları hazırlanmalıdır (Moreira, 2012).

Yangın geçiren bir orman sahasının orman oluşumu ve gelişimini tam olarak tamamlayamadan bir iki yıl gibi kısa süre içerisinde ikinci defa yangın geçirmesi halinde ise doğal süreçlerle yenilenme göreceli olarak çok daha yavaş olacak dolayısı ile de ortam yabancı istilacı türlerin yerleşmesi için çok açık kalacaktır (Keeley ve Brennan, 2012). İlk yangından sonra doğal yenileme sürecinde rezervler kullanılmış olacağı ve doğal orman oluşumu tam gelişimini tamamlayamadan ve yeni rezervler oluşturamadan ikinci yangın ile tahrip olacağ alanın kendini yenileme kapasitesi ve direnci azalarak güçsüz kalabilecektir. Bu tür alanlarda çok özel ve özenli restorasyon çalışmaları ile mineral ve organik madde takviyesi ile yerli türlerden tohum ve fidan desteği yapılması gerekecektir.

Yangın geçirmiş arazilerdeki kül ve diğer organik artıklar zengin ve kıymetli mineraller içerir. Kül ve toprak içerisindeki bitki besin maddeleri ve de yangının şiddetine bağımlı olarak arta kalan organik materyaller nem ile birbirine yapışarak koruyucu bir katman oluşturur. Bu katmanın korunması yanan arazilere yeni fidan dikiminden daha önemlidir. Mantarlar, bakteriler gibi mikro organizmalar ve likenler, yosunlar gibi küçük canlılardan oluşan kompozisyonların da desteği ile bu katmanın sağlayacağ koruyuculuk altında toprakta bekleyen tohumlar ve sporlar hizla yeni bitki topluluklarını üretecek ve destekleyecektir. Özellikle, onarılan orman sahalarında otsu bitkilerden, alçak çalılar ve yüksek ağaçlara kadar tüm bitkilerin hızlı sağlıklı gelişimleri için mikorizal funguslar ile bitkiler arasındaki simbiyotik oluşumun desteklenmesi büyük önem taşır. Bu ortaklığın yapıtaşları olan mantar sporlarını içeren mevcut organik toprak katmanının korunması çok önemlidir. Ağır iş makinaları ve yoğun insan e-ISSN: 2148-2683 hareketlilikleri koruyucu katmanın kırılıp yırtılması, sonucunda da erozyon kanalları oluşarak akmasına veya rüzgarla savrulmasına sebep olacaktır. $\mathrm{Bu}$ da öncü türlerin dahi yerleşmesini geciktireceğinden bitki örtüsünün yeşermesini, sağlıklı bir orman ekosisteminin restorasyonunu geciktirecektir.

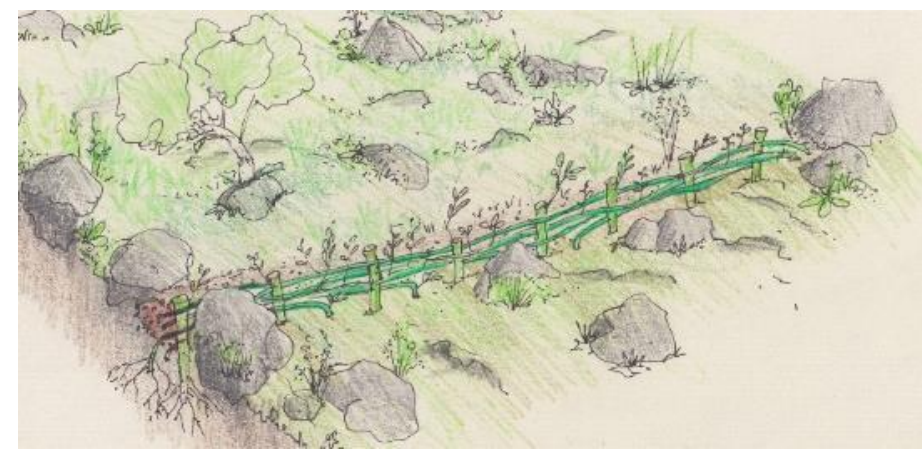

Şekil 5. Taze yeşil dallarla organik teraslama. Organic terrace implementation with fresh green twigs. (Imge yazartn orijinal eseridir, Image by the author, 2017)

Özellikle yüksek eğimli bölgelerde, organik toprak tabakasının, yangından arta kalan kül ve tohumların yangınları izleyen yağışlarla yıkanıp akmaması ve rüzgarla savrulmaması ve erozyon kanallarının oluşmaması için yeşil veya kuru ağaç ve çalı dalları ile teraslamalar ve setler yapılır. Yeşil ve canlılık içeren dallar ile tesis edilen setler, su ile beraber akan organik maddeler ile tohumları tutarak organik toprak katmanını korurken kendileri de köklenerek bitki kompozisyonunu zenginleştireceklerdir.

Bunun ötesinde toprağın üzerinin yaprak, dal ve tarımsal faaliyetlerden açığa çıkan atıklar benzeri organik materyallerden elde edilen yonga $(m u l c h)$ ile bir battaniye gibi örtülmesi acil önlemler olarak çok yarar sağlayacaktır. Arazi eğiminin yüksek olduğu bazı hallerde toprağın hava ve su almasına engel olmadan, yağmur damlalarının darbe etkisini azaltıp yumuşatarak erozyon tehdidini azaltacak sentetik veya doğada çözünebilen organik insan yapısı örtüler ile de kaplanabilir. Bunların yanında gerekli görülen bölgelere mikroorganizma ve öncü bitki aşılaması gibi çalışmalar da sağlıklı bir onarımı hızlandıracaktır. Yangın sonrası uygulamalara bağımlı olarak kül, ufalanmış toprak gibi tüm ince taneli organik veya inorganik materyallerin akarsulara, göllere ve denizlere ulaşması sucul yaşam alanları (aquatic habitat) için de ciddi tehdit oluşturur. Yangın söndürme çalışmalarında deniz suyu kullanılması durumu ise çok daha ciddi sorunlar ortaya çıkabilir. Aşırı tuzlanma toprağın asit-baz dengesini bozarak mikroorganizma faaliyetlerinin zayıflamasına sebep olacaktır. Tuzun ortamdaki olumsuz etkilerinin ortadan kaldırılması çok uzun zaman alabilecektir. Bitkilerin ortamda artan tuz konsantrasyonuna rağmen mikoriza ortaklığı sayesinde sağlıklı bir şekilde su ve besin maddelerini alabildiği tespit edilmiştir (Palta ve ark., 2010).

Restorasyon ve ağaçlandırma çalışmalarında endüstriyel ve doğal orman sınıflandırmasına önemle dikkat edilmelidir (Sedjo ve Botkin, 1997). Dünya genelinde endüstriyel üretim amacı için olduğu kadar iklim değişikliği, külltürel motivasyonlar ve rekreasyonal nedenlerle de plantasyon ağaçlandırmalarına eğilim artmaktadır. Küresel kereste ihtiyacının 2050 senesinde 6 milyar metreküpe erişeceği tahmin edilmektedir (McEwans ve d., 2020). Küresel dünyanın hız kazanan yaşam tarzları, artan ekonomik faaliyetleri ve nüfus artışına bağımlı olarak daha fazla insan daha fazla orman ürünü talep etmektedir. Dünyada kereste ve enerji kaynağı olarak çeşitli motivasyonlarla plantasyonlar aracılığı ile 
bu ihtiyaca cevap aranmaktadır. Böylece doğal, karışık ve biyolojik çeşitlik içeren sağlıklı ve zengin ormanların üzerindeki kereste üretim yükü kaldırılarak, doğal ormanlar biyolojik çeşitlik rezervleri ve kültürel rekreasyonel kaynaklar olarak korunabilecek ve genel olarak çok yönlü faydalar sağlanmış olacaktır. Türkiye'de de benzer taleplerin endüstriyel tüketim amaçlı plantasyon ağaçlıklarından karşılanması doğal orman varlığımızın sürdürülebilirliği için çok yararlı olacaktır.

Toprak koşulları, arazi eğimi, nem, güneşlenme ve rüzgar koşulları gibi farklılıklar gösteren yerel çevresel karakteristiklere göre bölgesel planlar hazırlanarak onarım ve iyileştirme programları geliştirilmelidir. Yeni bitki dikimi ancak toprak hazırsa yapılmalı ve tek tür olarak değil çalılardan ağaçlara, ibreli herdem yeşil türlerden yapraklı meyveli türlere çeşitlilik halinde yapılmalıdır. Kompozisyonda yörenin doğal ağaçları ve bitkilerinden sağlanan fidan ya da tohumlara öncelik verilmeli ve yoğunlukla yerli türler kullanılmalıdır. Böylece ormanların en büyük destekçisi olan (fauna) yabani hayvanlar için de beslenme ve barınma olanağı sağlayan habitatlar oluşturulacaktır. Coğrafi karakteristik özelliklere göre tespit edilen adalar ve bölgesel zonlar halinde korunacak ve/veya bitki ekimi ve dikimi gibi uygulamalar ile restore edilecek alanlar belirlenmelidir. Mikro ve makro ölçekli bölgeler bazında, belirlenen hedefler doğrultusunda hazırlanan kompozisyonlar aşamalı olarak fazlar dahilinde uygulanmalıdır. Yine aynı plan çerçevesinde koruma koridorları oluşturulabilir. Bu sayede yangın ilk başladığı ada ile sınırlanarak, yayılıp büyümesine engel olunacaktır. Bu koridorlar özellikle mutlak koruma gerektiren hassas ve endemik türlerin bulunduğu, önemle korunması gereken ve yangın riski olan bölgelere yangınların yayılmasına engel olmak için kullanılmalı ve yaygınlaştırılmalıdır. Koridorlar aynı zamanda ulaşım kolaylığı da sağlayan açıklıklar olarak da özellikle ulaşım güçlüğü olan bölgelerde yangın kontrolü için ve söndürme çalışmaları için çok önemli katkılar sağlayacaktır.

Ülkenin odun ve kereste gibi orman ürünleri ihtiyacı endüstriyel ormanlardan karşılanmak sureti ile doğal ve yarı doğal orman ekosistemleri, biyolojik çeşitlik içeren orman kompozisyonları biyosfer kaynakları ve rekreasyon olanakları ve çevresel estetik değerler olarak korunabilecektir. Orman yangınları ile henüz yangınlar başlamadan, önleme amaçlı planlamalar ile mücadeleyi başlatmak uzun vadede çok daha etkili ve ekonomik olacaktır.

\section{Hasar Tespiti Haritaları ve Restorasyon Planları}

Rehabilitasyon çalışmaları iki aşamalı olarak yürütülmelidir. İlk aşamada, bölgesel (makro) ölçekte ve gerekli görülmesi halinde de küçük bölgesel (mikro) ölçeklerde gerçekleştirilen haritalama çalışmaları ile hasar tespitleri yapılır. İkinci aşamada ise küçük bölgesel yerel ölçeklerde ve yeterli olmaları halinde de daha geniş bölgesel ölçeklerde ele alınan koruma, iyileştirme, ekosistem restorasyonu ağırlıklı uygulama plan kararları alınır. Uygulama planları, ilave detay planları ve plan notları ile beraber teraslama, örtüleme, mutlak koruma, organik materyal takviyesi, tohum ve fidan desteği ile yeni bitki örtüsü oluşturulması gibi yere özel koruma ve restorasyon uygulama kararlarını hayata geçirir. $\mathrm{Bu}$ planlar, 'Orman Arazisi ve Orman Ekosistemi Koruma Planları' şeklinde ulusal çevre düzeni planlarından itibaren gerekli görülen ölçeklere uygun olarak uygulama planlarını da kapsayacak şekilde ülkesel plan hiyerarşisine entegre edilmelidir.

\subsection{Hasar Tespiti Haritaları 1/25 000 - 1/1000}

Bölgesel ölçekten, küçük yerel alan ölçeğine kadar geniş bir yelpazede ele alınabilecek Orman Arazisi ve Orman Ekosistemi Koruma Planları pafta anahtarında (lejant) ele alınacak alt bölge zonları ve uygulama unsurları şunlardır.

- Yangın sahasının büyüklüğü ve yangının şiddetinin tespiti (yüzey-örtü yangını, tümden yanmış olma hali v.b.)

- Yangının başlangıç yeri ve ilerleme yönü ile kontrol altına alındığı noktaların tespiti

- Yanmanın şiddetine bağlı olarak mevcut bitki varlığının tespiti, köklerin ve kambiyum dokusunun sağlıklılığı.

- Yangın sahasının topoğrafik yapısı, eğim şiddeti, eğim yönü, toprak yapısı ve toprak derinliği.

- Yangının topraktaki etki derinliğinin analizi ve topraktaki canlılığın tespiti.

- Biyolojik kaymak katmanının varlığı ve organik madde varlığ 1 .

- İkincil bir yangın olması halinde yanma alanı sınırları ve yangınlar arasındaki sürenin miktarı.

- Bölgesel iklimsel özellikler, mevsimler yağış rejimi, hâkim rüzgar yön ve şiddetleri.

\subsection{Koruma, İyileştirme ve Restorasyon Plan, Plan Detayları ve Plan Notları 1/25 000 - 1/1000}

Üst ölçekte elde edilen yukarıdaki analiz ve tespitler doğrultusunda çok disiplinli uzman ekipler tarafından bir sonraki aşamada koruma ve restorasyon hedefli uygulama plan ve programları ile plan notları ve plan detayları geliştirilir. Bölgesel çevre düzeni planları ölçeklerine kadar geniş ölçekleri de kapsayabilecek olan uygulama planları ve notları aşağıdaki pafta anahtarı unsurları ile koruma, iyileştirme ve restorasyon eylemelerini hayata geçirir.

- Koruyarak, kendi halinde bırakılarak doğal süreçlerle ve öz kaynakları ile kendini yenileyebilecek bölgeler, koridorlar.

- Tüm insan faaliyetleri kısıtlanarak mutlak koruma altına alınması gereken sahalar.

- Koruyucu örtü ve teraslama önlemleri ile erozyondan korunarak doğal süreçlerle ve öz kaynakları ile kendini yenileyebilecek bölgeler.

- Yüzey su akışını yavaşlatan, engelleyen ve dinlendiren, suyun ve taşıdığı materyallerin tutularak, süzülüp çökeltildiği su tutma terasları ve kanalları tesis edilmesi gereken bölgeler.

- Organik set ve teras tesis edilecek eğimli yüzeyler.

- Organik madde, mikoriza ve toprak edafonu aşılanması gereken bölgeler

- İstilacı yabancı türlerden arındırılması gereken bölgeler.

- Yabanci türlerin istilası tehdidi altında bulunan ve gözlem altında tutulması gereken hassas bölgeler.

- Öncü bitkiler, otsu bitkiler, çalılar ve ağaç fidan ve tohumları ile desteklenerek yeni ve karışık orman oluşturulacak bölgeler.

- Koruma koridoru güzergahları. 


\section{Sonuç}

Öncelikle, ormanların salt ağaçtan oluştuğu ve her yerin orman olması gerektiği yanılsaması terk edilmelidir. Kamuoyunun sağlıklı ormanlar, orman ekolojisi ve ormanların temel yapı taşları hakkında bilgilendirilmesi, yangına karşı koruma, yanan sahaların korunmasi ve rehabilitasyonu çalışmalarında kamuoyunun ve ilgili kurumların etkili katılımlarını sağlayacaktır. Rehabilitasyon çalışmaları ağaçlık tesisinden çok sağlıklı dengeli, zengin ekolojik sistemlerin üretilmesine odaklanmalıdır. Çayırlar, otlaklar, makilikler, sulak alanlar ve ormanlar gibi biyolojik çeşitliğe sahip doğal yaşam ortamlarının (habitatlar) gelişimi desteklenmelidir. Kırsal çevrelerde yer alan bu habitatlar çok geniş ve bölgesel bir ağın üyesi olarak küresel sağlıklı doğal çevrelere bütüncül katkılar sağlarlar. Yangın, kuraklık, artan azalan sıcaklıklar, genel iklimsel veya sosyokültürel değişiklikler karşısında doğa veya insan kaynaklı baskılar ve tahribatlar karşısında bütüncül bir ekosistemler topluluğu olarak direnç kazanırlar. Tahrip olan orman alanlarının kendilerini yenileyebilmesi için ağaç fidanından önce sağlıklı çevrelerde yer alan bütüncül oluşumlara ihtiyacı vardır. Sakin ve sükunetle, bilgiyle hareket edilip sadece doğal süreçlerin önünü açarak destek olmak ve bu süreçte koruma önlemlerini almak yeterli olacaktır. Bilimsel veriler ve bilgilerle aydınlatılan paydaşlar, orman yangınları sonrasındaki eylemlere uyum içerisinde katılarak, ortak hedefler doğrultusunda gerçekleştirilen uygulamalarda pozitif etkiler sağlayacaklardır.

\section{Kaynakça}

Akyol, A. ve Tolunay, A. (2006). Türkiye'de Sürdürülebilir Orman Kaynakları Yönetimi, İlkeleri, Göstergeleri ve Uygulamaları. Süleyman Demirel Üniversitesi, Fen Bilimleri Enstitüsü Dergisi, 10-2, 221-234.

Alkan, S. (2014). Kırsal Nüfus Değişiminin, Ormanlar ve Ormancılık Üzerine Etkileri (Trabzon İli Örneği). Kastamonu Üni., Orman Fakültesi Dergisi, 14 (1) 69-78.

Bilgili, Adnan, Okan Demir, Mahmut Daşcı. (2017). Orman Yangınlarının Önlenmesinde Sürdürülebilir Uygulama: Kontrollü Hayvan Otlatma. ADÜ. Ziraat Dergisi, 14(1):8793.

Blair, John M., Patrick J. Bohlen, Diana W. Freckman.(1997) Soil Invertebrates as Indicators of Soil Quality. In: John W. Doran, Alice J. Jones (eds) Methods for Assessing Soil Quality, Volume 49. SSSA Special Publications. Madison Wisconsin, USA.

Bowker, M. A. (2007) Biological Soil Crust Rehabilitation in Theory and Practice: An Underexploited Opportunity. Restoration Ecology Vol. 15, No. 1, pp. 13-23.

Brianne, Palmer, Hernandez Rebecca, Lipson Davis. (2020). The fate of biological soil crusts after fire: A meta-analysis. Global Ecology and Conservation 24, e01380.

Chotte JL. (2005) Importance of Microorganisms for Soil Aggregation. In: Varma A., Buscot F. (eds) Microorganisms in Soils: Roles in Genesis and Functions. Soil Biology, vol 3. Springer, Berlin, Heidelberg.

Dalling, J.W. (2008) Pioneer Species. In Encyclopedia of Ecology, Five-Volume Set (pp. 2779-2782). Elsevier Inc.

Elmas, Ç. ve Sönmez, Y. (2008). Veri Birleştirme Tabanlı Orman Yangını Önleme ve Yönetim Sistemi. Politeknik Dergisi, 11 (2), 99-108.

Ericsson, Tom (1994) Nutrient Dynamics and Requirements of Forest Crops. New Zealand Journal of Forestry Science 24(2/3): 133-68.
Erzurumlu, Gülden S. ve Kara, Emine E. (2014) Mikoriza Konusunda Türkiye'de Yapılan Çalışmalar. Türk Bilimsel Derlemeler Dergisi 7 (2): 55-65.

Finegan, B. (1984). Forest Succession. Nature, Vol. 312-8, pg. 109.

Giri B., Giang P.H., Kumari R., Prasad R., Varma A. (2005) Microbial Diversity in Soils. In: Varma A., Buscot F. (eds) Microorganisms in Soils: Roles in Genesis and Functions. Soil Biology, vol 3. Springer, Berlin, Heidelberg.

Gülen, İlhan ve Metin Özdönmez (1981). Türkiye'de Orman ve Ormancilık. Orman Fakültesi Dergisi, B/31-2.

Gümüş, Cantürk. (2016) Historical development of forestry education in the context of forest resources management in Turkey. Turkish Journal of Forestry, 17(1): 93-98.

Kara, Ömer ve Tilki, Fahrettin (2001) Mikoriza ve Ormanc1likta Kullanımı. İstanbul Üniversitesi, Orman Fakültesi Dergisi, $\mathrm{B} / 51-1$.

Keeley, E. Jon, Teressa J. Brennan. (2012). Fire-driven alien invasion in a fire-adapted ecosystem. Oecologia, 169:1043

Keeley, E. Jon. (2012). Fire in Mediterranean Ecosystems: Ecology, Evolution and Management. Cambridge University Press.

McEwan, A., ve diğerleri. (2020) Past, present and future of industrial plantation forestry and implication on future timber harvesting technology. J. For. Res. 31(2):339-351

Moreira F. Ve diğerleri. (2012) Setting the Scene for Post-Fire Management. In: Moreira F., Arianoutsou M., Corona P., De las Heras J. (eds) Post-Fire Management and Restoration of Southern European Forests. Managing Forest Ecosystems, vol 24. Springer, Dordrecht.

North ve d. (2015). Reform Forest Fire Management. Science. Vol. 349, Issue 6254, pp. 1280-1281.

Noss, Reed F. ve diğerleri (2006) Managing fire-prone forests in the western United States. Front Ecol Environ; 4(9): 481-487

Ortaş, İbrahim ve d. (1999) Mikoriza Sporlarının Üretim Tekniği ve Tarımda Kullanım Olanakları. Tr. J. of Agriculture and Forestry, 23, Ek Sayı 4, 959-968, TÜBİTAK.

Palta, Şahin ve ark. (2010). Arbüsküler Mikorizal Funguslar (AMF), Bitki ve Toprakla İlişkileri, Mera Islahındaki Önemleri. Bartın Orman Fakültesi Dergisi, 12:18, 87.

Sedjo, Roger A. Ve Daniel Botkin (1997) Using Forest Plantations TO SPARE Natural Forests, Environment: Science and Policy for Sustainable Development, 39:10, 1430.

Srivastava, Kajal and A. K. Sharma. (2011) Arbuscular Mycorrhizal Fungi in Challenging Environment-A Prospective. In: Fulton, Susanne M. (ed.) Mycorrhizal Fungi: Soil, Agriculture and Environmental Implications, Nova Science Publishers, Inc., New York.

Şen, Gökhan ve Gür, Ersin (2018). Endüstriyel ağaçlandırmalar için en uygun tür seçiminde analitik hiyerarşi süreci yönteminin kullanılması: Kastamonu İli örneği. Türkiye Ormanc1lık Dergisi. 19(1): 63-75.

Tavşanoğlu, Çağatay, Şikri S. Çatav, Barış Özüdoğru (2015) Firerelated germination and early seedling growth in 21 herbaceous species in Central Anatolian steppe. Journal of Arid Environments 122, 109-116.

Wilson, O. Edward (1984) Biophilia. Cambridge, MA: Harvard University Press.

Wolters, Volkmar (1991) Soil Invertebrates - Effects on Nutrient Turnover and Soil Structure - A Review. Angenommen 21 Mai. 